\title{
Pengembangan Media Pembelajaran Virtual Physics Laboratory (ViPhyLab) Dalam Praktikum Hukum Kirchhoff
}

\author{
Dina Rosdiana ${ }^{1}$, Andri Suherman ${ }^{2}$, dan Dina Rahmi Darman ${ }^{3}$ \\ ${ }^{1}$ Program studi Pendidikan Fisikea, Universitas Sultan Ageng Tirtayasa \\ ${ }^{2}$ Program studi Pendidikan Fisika, Universitas Sultan Ageng Tirtayasa \\ ${ }^{3}$ Program studi Pendidikan Fisika, Universitas Sultan Ageng Tirtayasa \\ e-mail: \\ 1 dinarosdiana@gmail.com \\ 2 andris_mada@yahoo.com \\ 32dina_rd@untirta.ac.id
}

\begin{abstract}
.
This study is to study the feasibility of learning media Virtual Physics Lab (ViPhyLab) in Kirchboff's Law Practice and to study student responses to learning media Virtual Physics Lab (ViPhyLab) in Kirchhoff's Law Practicum. The research method used is the Research and Development method ( $\mathrm{R} \& \mathrm{D})$ according to Sugiyono. Feasibility of Virtual Physics Lab results of development based on the results of validation that is equal to $87.45 \%$ with a very feasible category. Limited trials were conducted on 16 students of class XI MIPA at High School AlFath Cilegom which were used to determine students' responses regarding ViPhyLab media. The results of the trial are limited as much as $90.4 \%$ of students approve the ViPhyLab media in a very good category.
\end{abstract}

Keywords: learning media, virtual physics laboratory, Kirchhoff's law

\begin{abstract}
ABSTRAK.
Penelitian ini bertujuan untuk mengetahui kelayakan media pembelajaran Virtual Physics Lab (ViPhyLab) dalam Praktikum Hukum Kirchhoff. Metode penelitian yang digunakan adalah metode Research and Development (R\&D) menurut Sugiyono, dengan subjek penelitian ini adalah 3 validator untuk mengetahui kelayakan media ViPhylab dan 16 siswa kelas XI MIPA SMA Al-Fath Cilegon yang digunakan untuk mengetahui tanggapan siswa terhadapa media ViPhyLab. Hasil penelitian menyatakan kelayakan media ViPhyLab hasil pengembangan yaitu sebesar 87,45\% dengan kategori sangat layak dan tanggapan siswa terhadap media ViPhyLab menyatakan sebanyak $90,4 \%$ siswa menanggapi media ViPhyLab dengan kategori sangat baik.
\end{abstract}

Kata Kunci: media pembelajaran, virtual physics lab, hukum kirchhoff

\section{PENDAHULUAN}

Salah satu masalah yang ditemukan dalam pelaksanaan kurikulum tahun 2013 adalah tidak semua kompetensi keterampilan dapat dilaksanakan dengan baik. Hal ini dikarenakan masih kurangnya sarana dan prasarana di sekolah seperti bahan ajar (Dina, dkk: 2017), media pembelajaran (Wibowo, dkk: 2016), laboratorium, dan virtual simulasi (Wibowo, dkk: 2017). 
Oleh karena itu, untuk mengatasi masalah ini, laboratorium virtual dirancang untuk memungkinkan peserta didik melakukan eksperimen dengan berinteraksi dengan perangkat nyata, instrumen nyata, dan mekanisme visualisasi melalui platform simulasi yang tepat (Wibowo, dkk: 2017). Pernana, N.D (2018) menyatkan bahwa praktikum dapat menjadi lebih efektif dan efisien dengan adanya praktikum virtual pada materi kinematika gerak lurus.

Penelitian terdahulu yang terkait dengan Virtual Physics Lab adalah penelitian yang dilakukan Swandi, dkk (2014) di dalam penelitiannya berkaitan dengan Virtual Lab pada materi fisika inti dan radioaktivitas. Selanjutnya penelitian oleh Wibowo, dkk (2018) tentang Virtual Physics Laboratory sebagai asesmen karakter. Selanjutnya penelitian yang dilakukan Irfan, dkk (2015) adalah penelitian tentang pengembangan Virtual Lab pada materi fisika modern. Fitra dan Herru (2017), penelitiannya bersangkutan dengan Virtual Lab pada materi dinamika rotasi. Kemudian, penelitian yang dilakuan oleh Gunawan, dkk (2018) adalah media Virtual Lab untuk konsep fluida statis. Sehingga belum ada penelitian tentang pengembangan Virtual Lab pada materi Hukum Kirchhoff.

Celik, dkk (2015) mengungkapkan ada beberapa perangkat lunak yang dapat diterapkan untuk instruksi simulasi yang dibantu, seperti: PCCL, Physics Crocodile, Phet dan Algodoo. Semua program memiliki sifat yang berbeda dan keunikan. Di dalam PCCL terdapat simulasi Hukum 1 Kirchhoff dan Hukum 2 Kirchhoff tetapi tidak ada simulasi 1 loop maupun 2 loop.

Dari hasil penelitian terdahulu, belum ada penelitian Virtual Physics Laboratory (ViPhyLab) sebagai solusi praktikum Hukum Kirchhoff dan diperkuat lagi dengan hasil studi pendahuluan oleh guru dan siswa di dua sekolah yaitu SMA Al-Fath Cilegon dan SMA N 1 Cilegon bahwa guru di dua sekolah tersebut 100\% setuju dengan adanya ViPhyLab dalam praktikum hukum kirchhoff karena ViPhyLab dapat memudahkan guru menyampaikan konsep hukum Kirchhoff dan siswa di kedua sekolah tersebut $100 \%$ setuju dengan diadakannya ViPhyLab sebagai solusi jika praktikum hukum kirchhoff tidak dilaksanakan, karena siswa merasa kesulitan dalam memahami konsep hukum kirchhoff dan adanya ViPhyLab dapat membantu siswa untuk memahami hukum kirchhoff. Berkaitan dengan masalah tersebut, maka perlu dikernbangkan ViPhyLab pada materi Rangkaian Arus Searah khususnya Hukum Kirchhoff agar siswa seolah-olah melakukan praktikum sebagaimana mestinya. Berkenan hal tersebut, maka diperlukan penelitian mengenai "Pengembangan Media Pembelajaran Virtual Pbysics Laboratory (ViPbyLab) dalam Praktikum Hukum Kirchhoff.

\section{METODOLOGI}

Metode penelitian yang digunakan adalah metode Research and Development (R\&D) yang digunakan untuk menghasilkan suatu produk tertentu, dan untuk menguji keefektifan produk yang dihasilkan tersebut. Uji coba dilakukan secara terbatas dengan subjek uji coba penelitian ini adalah siswa XI MIPA SMA Al-Fath Cilegon yang terdiri dari 16 siswa yang diminta tanggapannya melalui angket tentang desain perangkat, pembelajaran dan komunikasi pada produk ViPhyLab. Selain itu, ViPhyLab ini divalidasi oleh validator yang berjumlah 3 orang dengan menggunakan instrumen penilaian angket yang menilai aspek program media, aspek tampilan, aspek kebahasaan, aspek kebenaran konsep dan aspek kedalaman konsep.

\section{TEMUAN DAN PEMBAHASAN}

Hasil angket kebutuhan guru di SMA N 1 Cilegon dan SMA Al-fath Cilegon menunjukan bahwa guru $100 \%$ setuju dengan diadakannya ViPhyLab sebagai solusi jika praktikum materi hukum kirchhoff tidak bisa dilaksanakan secara riil, guru di kedua sekolah tersebut juga belum pernah membuat media pembelajaran sendiri, karna membutuhkan waktu yang lama untuk membuatnya. Hasil kebutuhan siswa menunjukan bahwa $100 \%$ siswa tidak melaksanakan praktikum hukum kirchhoff di laboratorium karena $70 \%$ siswa menyatakan alat yang digunakan 
untuk praktikum terbatas dan 100\% siswa setuju dengan diadakannya ViPhyLab sebagai solusi jika praktikum hukum kirchhoff tidak bisa dilaksanakan. Sehingga peneliti akan melanjutkan penelitian dalam mengembangkan ViPhyLab untuk praktikum hukum kirchhoff.

Pembuatan ViPhyLab dilakukan dengan menggunakan software Adobe Flash Professional CS 6. Tahap pembuatan ViPhyLab ini berdasarkan storyboard yang telah dibuat. Tampilan ViPhyLab terdiri dari beberapa bagian yaitu pendahuluan dan bagian isi. Bagian pendahuluan merupakan bagian awal media ViPhyLab ini. Ini adalah halaman login, halaman selamat datang dan daftar menu. Halaman login ini berfungsi untuk menuliskan username dan password. Tampilan halaman login dapat dilihat gambar 1.

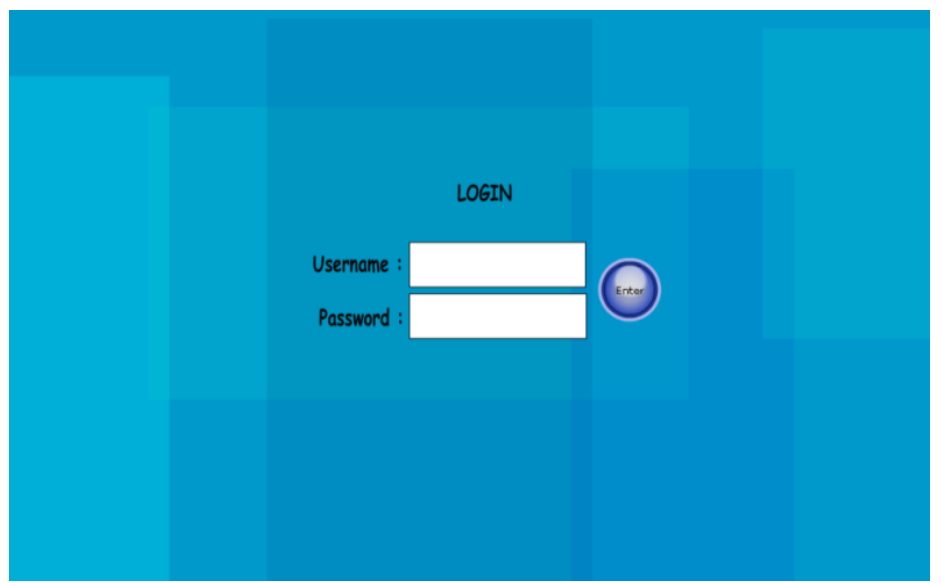

Gambar 1. Halaman login pengguna ViPhyLab hasil pengembangan

Setelah pengguna memasukan username dan password dengan benar,lalu klik tombol enter, pengguna akan dialihkan ke halaman selamat datang yang menandakan bahwa pengguna telah berhasil masuk. Tampilan halaman selamat datang dapat dilihat gambar 2

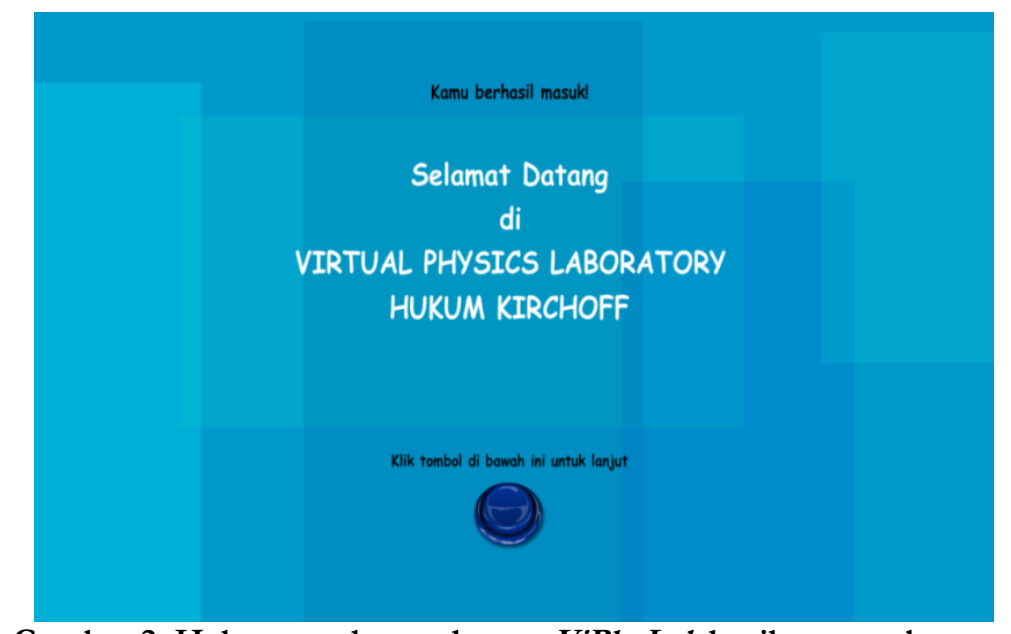

Gambar 2. Halaman selamat datang ViPhyLab hasil pengembangan

Jika pengguna berhasil masuk, maka akan muncul tampilan seperti gambar 2, kemudian pengguna klik tombol biru untuk melanjutkannya. Setelah pengguna klik tombol biru tersebut, pengguna akan dialihkan ke halaman Home yang terdapat beberapa menu dan petunjuk penggunaan. Untuk lebih jelasnya lihat gambar 3 berikut. 


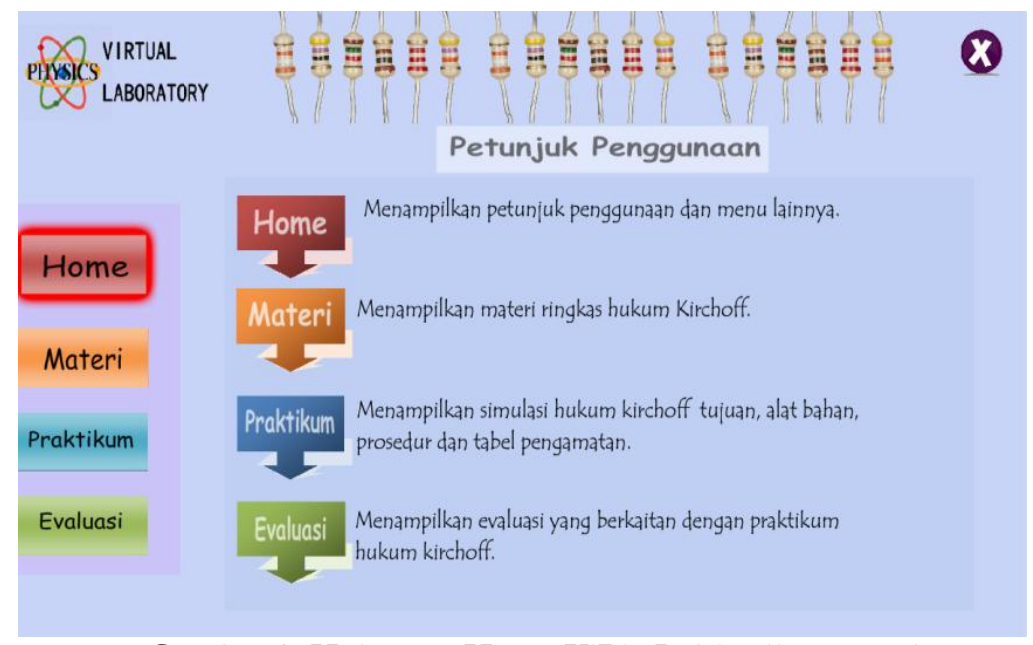

Gambar 3. Halaman Home ViPhyLab hasil pengembangan

Bagian isi ViPhyLab terdapat 4 macam menu yang bisa dipilih oleh pengguna. Empat menu tersebut terdiri dari home, materi, praktikum dan evaluasi. Pada bagian home terdiri dari petunjuk penggunaan media ViPhyLab yang terdapat pada gambar 3. Pada gambar tersebut, pengguna dapat memahami petunjuk penggunaan agar lebih memudahkan dalam menjalankan ViPhyLab.

Pada bagian materi terdapat landasan teori secara singkat mengenai hukum 1 kirchhoff dan hukum 2 kirchhoff. Diharapkan pengguna dapat membaca lalu memahami teori hukum-hukum kirchhoff sebelum melakukan praktikum di dalam ViPhyLab. Bagian materi ini dapat dilihat pada gambar 4.

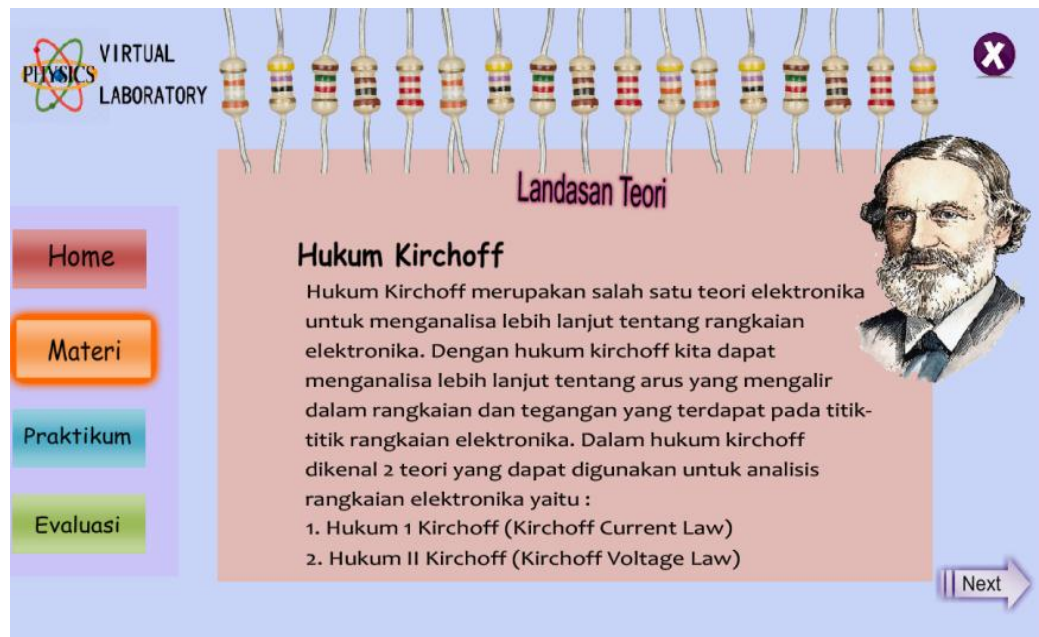

Gambar 4. Bagian materi hukum kirchhoff

Pada bagian materi hukum kirchhoff terdapat tombol "Nexp", tombol ini berfungsi untuk melanjutkan ke halaman selanjutnya yaitu materi hukum 1 kirchhoff. materi hukum 1 kirchhoff dapat dilihat pada gambar 5. 


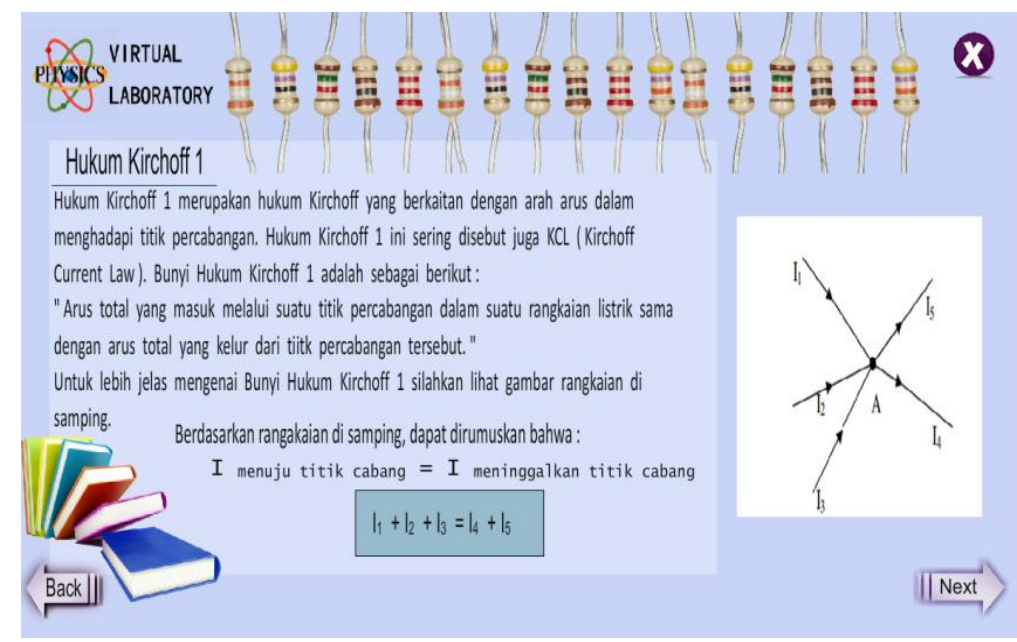

Gambar 5. Bagian materi hukum 1 kirchhoff

Bagian materi hukum 2 kirchhoff menjelaskan hukum 1 kirchhoff secara ringkas. Pada bagian ini terdapat tombol "Back" yang berfungsi untuk kembali ke tampilan sebelumnya dan tombol "Next" yang berfungsi untuk melanjutkan ke tampilan selanjutnya yaitu bagian materi hukum 2 kirchhof, dapat dilihat pada gambar 6.

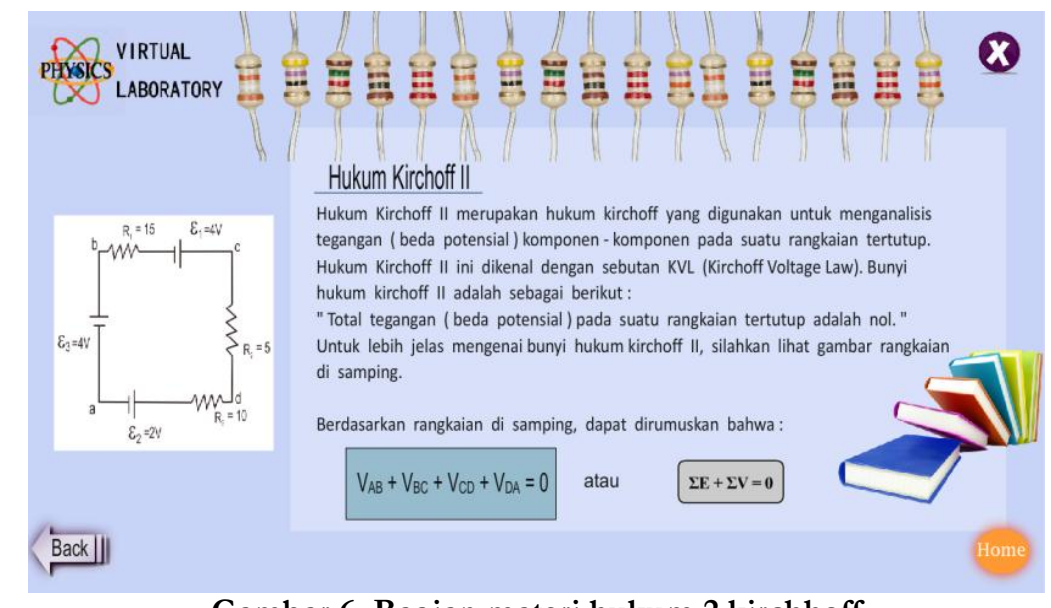

Gambar 6. Bagian materi hukum 2 kirchhoff

Pada bagian materi hukum 2 kirchhoff menjelaskan hukum 2 kirchhoff secara ringkas. Pada bagian ini terdapat tombol "back' yang fungsinya untuk kembali ke halaman sebelumnya yaitu bagian materi hukum 1 kirchhoff. dan tombol "Home" berfungsi untuk kembali ke halaman home.

Pada saat klik tombol praktikum, pengguna akan dialihkan ke bagian praktikum hukum kirchhoff. Untuk lebih jelasnya lihat gambar 7. 


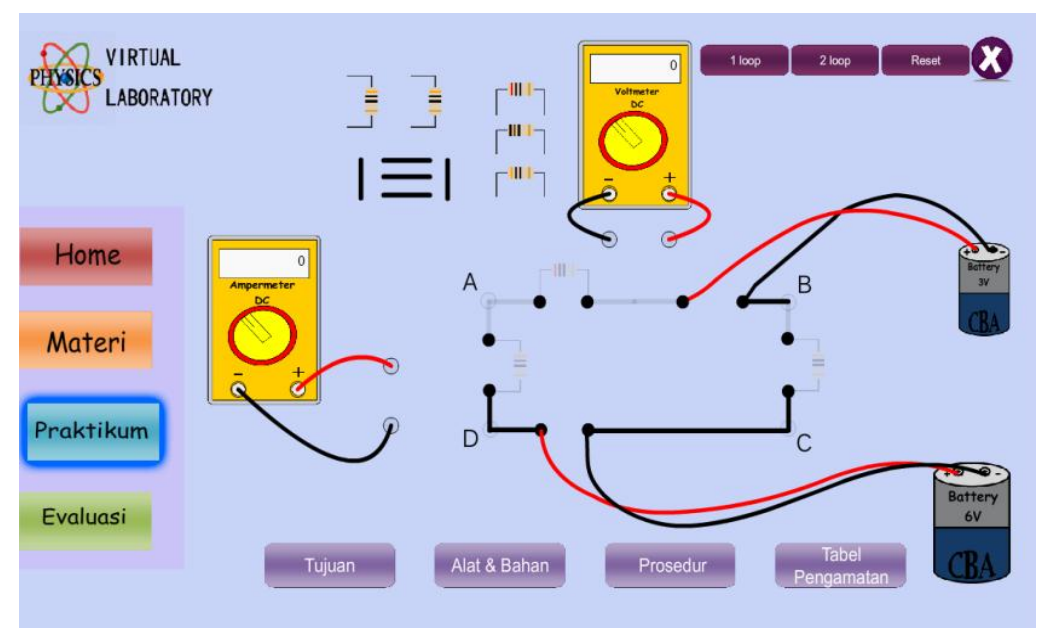

Gambar 7. Bagian praktikum hukum kirchhoff 1 loop

Pada bagian praktikum hukum kirchhoff terdapat beberapa resistor dan lainnya yang dapat pengguna pasangkan ke rangkaian, dilengkapi dengan ampermeter dan voltmeter yang dapat digunakan. Ampermeter digunakan untuk mengukur arus, dan ampermeter dipasang secara seri, sedangkan voltmeter digunakan untuk mengukur tegangan dan dipasang secara paralel. Bagian ini di dalamnya terdapat beberapa tombol yaitu 1 loop, 2 loop, reset, dan tombol lainnya adalah tujuan, alat dan bahan, prosedur, dan tabel pengamatan. Pada saat klik tombol " 2 loop" pengguna akan dialihkan ke bagian praktikum hukum kirchhoff 2 loop yang dapat dilihat pada gambar 8 .

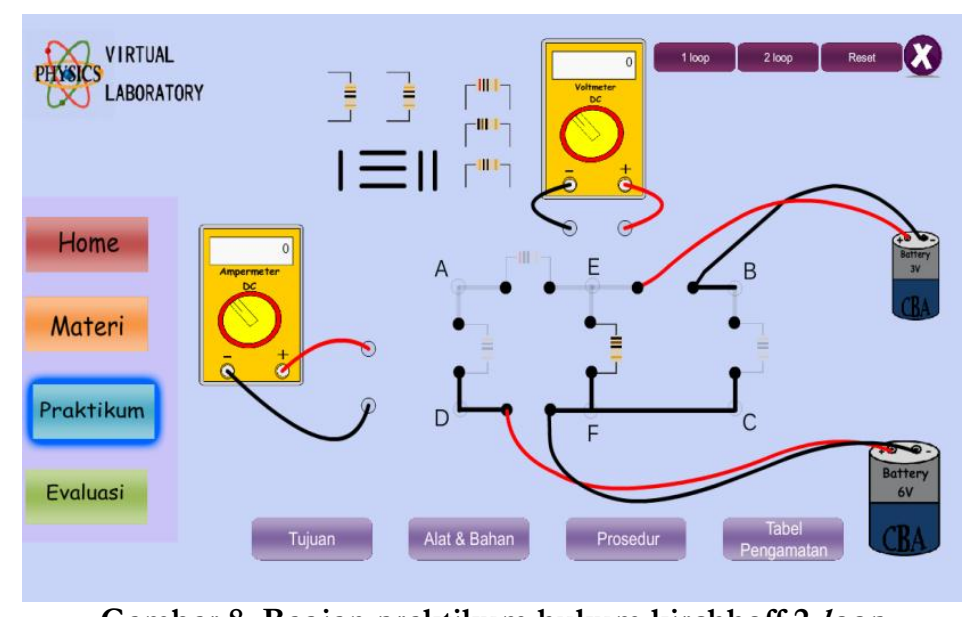

Gambar 8. Bagian praktikum hukum kirchhoff 2 loop

Dan ketika klik tombol "1 loop" pengguna akan dialihkan ke bagian seperti pada gambar 7. Ketika klik tombol "reset" resistor dan kabel yang dipasang ke dalam rangkaian akan kembali ke posisi semula yaitu resistor dan kabel akan terlepas dari rangkaian tersebut.

Seperti yang sudah dijelaskan, bagian praktikum terdapat tombol lainnya yaitu tujuan, alat bahan, prosedur dan tabel pengamatan. Pada saat klik tombol "tujuan" pengguna dapat melihat tujuan praktikum sebelum melakukan praktikum hukum kirchhoff. tujuan praktikum digunakan sebagai acuan praktikum. Tampilan bagian tujuan dapat dilihat pada gambar 9. 


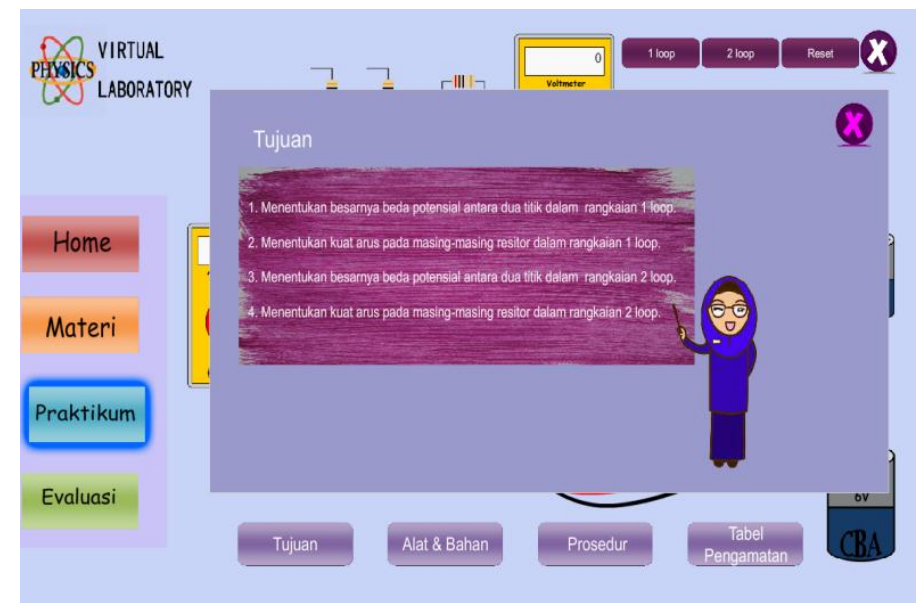

Gambar 9. Bagian tujuan praktikum gambar 10.

Pada saat pengguna klik tombol "Alat dan bahan" akan muncul tampilan seperti pada

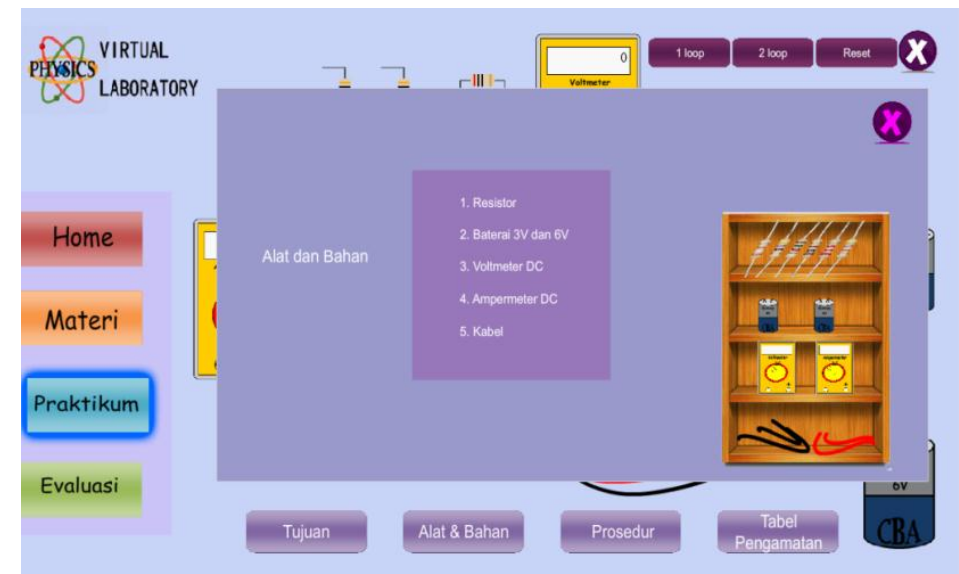

Gambar 10. Bagian alat dan bahan praktikum

Tombol ini terdiri dari alat dan bahan yang dilengkapi gambar. Alat dan bahan digunakan untuk praktikum seperti resistor, baterai, ampermeter, voltmeter dan kabel. Pada saat klik tombol "Prosedur" pengguuna akan dialihkan ke tampilan seperti pada gambar 11.

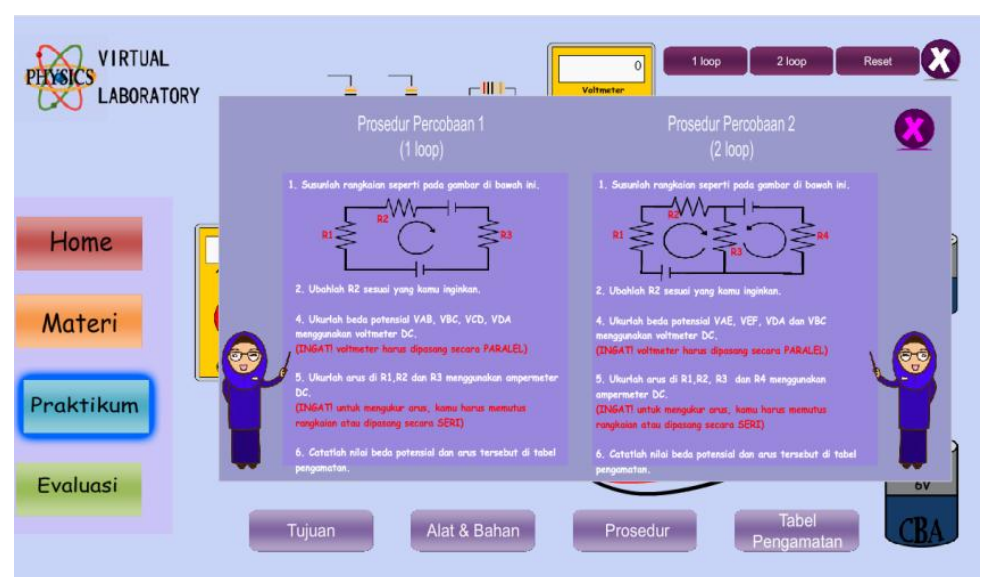

Gambar 11. Bagian prosedur praktikum

Bagian prosedur berfungsi sebagai langkah-langkah yang akan pengguna lakukan pada saat praktikum hukum kirchhoff 1 loop maupun 2 loop, sehingga pengguna tidak bingung pada saat melakukan praktikum. 
Tombol selanjutnya yaitu tombol "Tabel pengamatan". Pada saat pengguna klik tombol tersebut, pengguna akan dialihkan ke tampilan seperti pada gambar 12.

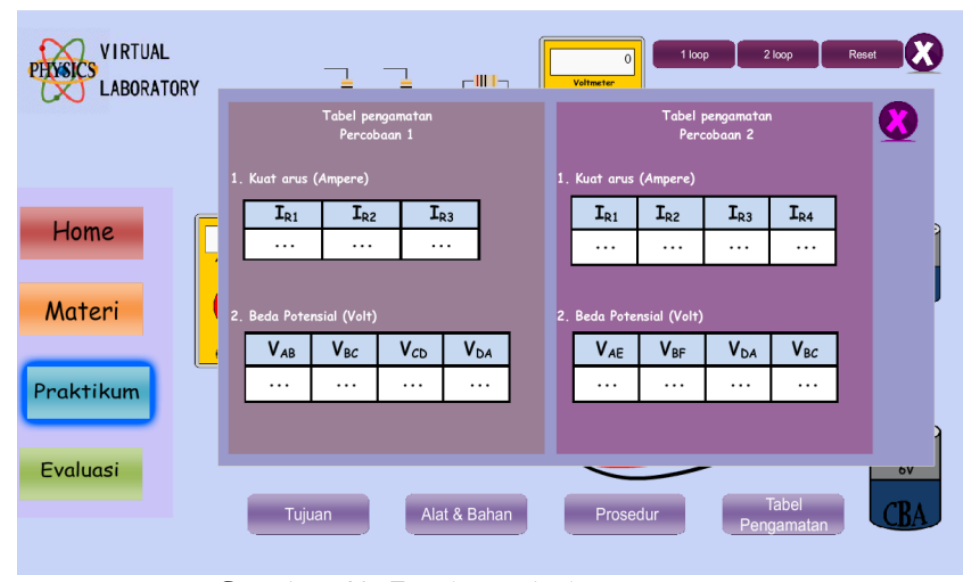

Gambar 12. Bagian tabel pengamatan

Tabel pengamat digunaan untuk sebagai acuan pengguna pada saat mencari nilai arus dan tegangan. Sehingga pengguna akan tahu, titik-titik mana saja yang digunakan untuk mencari nilai arus dan tegangan.

Pada menu home ViPhyLab juga terdapat tombol evaluasi. Menurut Suharsimi Arikunto (2003), arti evaluasi adalah serangkaian kegiatan yang bertujuan untuk mengukur tingkat keberhasilan suatu program pendidikan. Sehingga dapat disimpulkan evaluasi yang digunakan pada media ViPbyLab berfungsi untuk mengukur tingkat keberhasilan pencapaian pembelajaran pengguna setelah melakukan praktikum. Bagian evaluasi ini terdiri dari 5 soal, dimana soal dibuat berdasarkan tujuan praktikum hukum kirchhoff 1 loop maupun 2 loop. Tampilan evaluasi dapat dilihat pada gambar 13 berikut

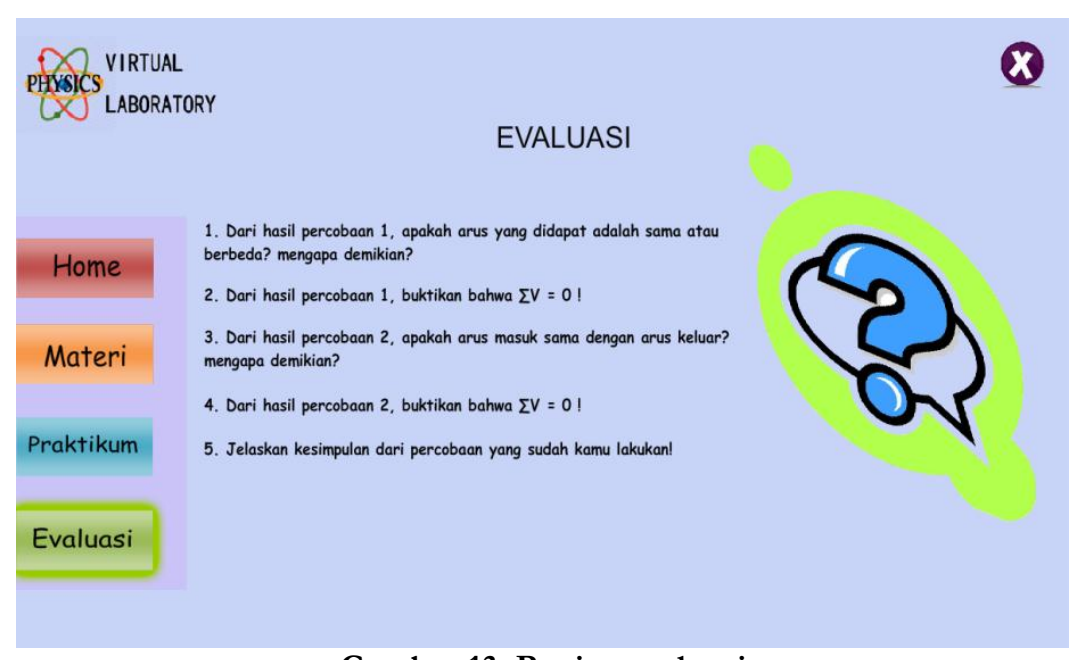

Gambar 13. Bagian evaluasi

Dalam tahap pengujian, media pembelajaran ViPhyLab ini divalidasi oleh 3 orang validator dengan menggunakan instrumen penilaian angket yang terdiri dari aspek program media, aspek tampilan, aspek kebahasaan, aspek kebenaran konsep dan aspek kedalaman konsep. Berdasarkan hasil validasi didapatkan persentase rata-rata, yang hasilnya disajikan grafik pada gambar berikut. 


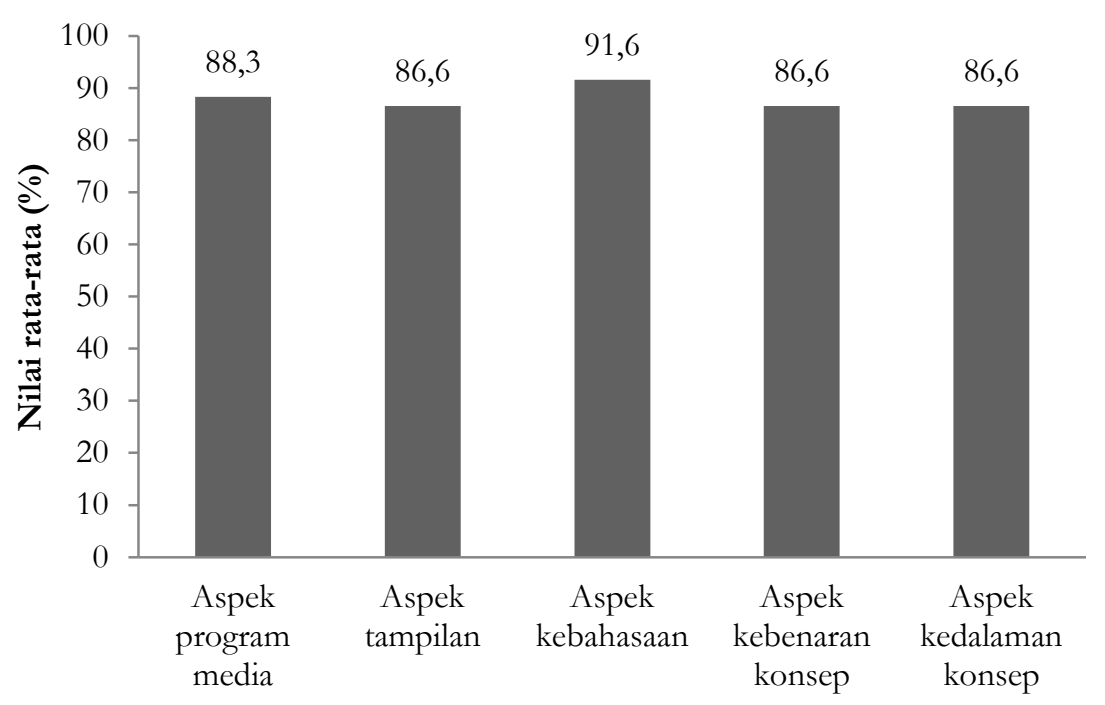

Gambar 14. Persentase Rata-rata Setiap Aspek

Hasil rata-rata pada aspek program media memiliki nilai rata-rata 88,3\% dengan kategori sangat layak. Hal ini dikarenakan adanya petunjuk penggunaan di dalam media ViPhyLab. Dan persentase rata-rata yang diperoleh aspek tampilan yaitu 86,6\% kategori sangat layak, hal ini juga dikarenakan adanya tombol/button yang jelas sehingga mempermudah pengguna dalam menjalankan media ViPbyLab.

Pada aspek kebahasaan mendapatkan persentase tertinggi dari kelima aspek tersebut yaitu sebesar 91,6\%. Persentase tertinggi ini didapat karena penulisan sesuai dengan kaidah bahasa Indonesia dan EYD. Yang keempat adalah aspek kebenaran konsep, pada aspek ini mendapatkan persentase rata-rata sebesar $86,6 \%$ dengan kategori sangat layak. Hal ini dikarenakan adanya kejelasan materi sesuai dengan kompetensi inti dan kompetensi dasar, langkah percobaan dan simulasi yang sesuai dengan hukum kirchhoff. Aspek yang kelima adalah kedalaman konsep memperoleh persentase yang sama dengan aspek tampilan dan aspek kebenaran konsep, yaitu sebesar 86,6\% dengan kategori sangat layak. Dari hasil persentase kelima aspek diatas, didapat persentase rata-rata keseluruhan yaitu sebesar $87,45 \%$ dengan kategori sangat layak. Sehingga media ViPhyLab dinyatakan valid dan sangat layak untuk digunakan.

Selanjutnya, hasil persentase rata-rata tanggapan siswa yang terdiri dari 3 aspek yaitu desain perangkat, pembelajaran dan komunikasi.

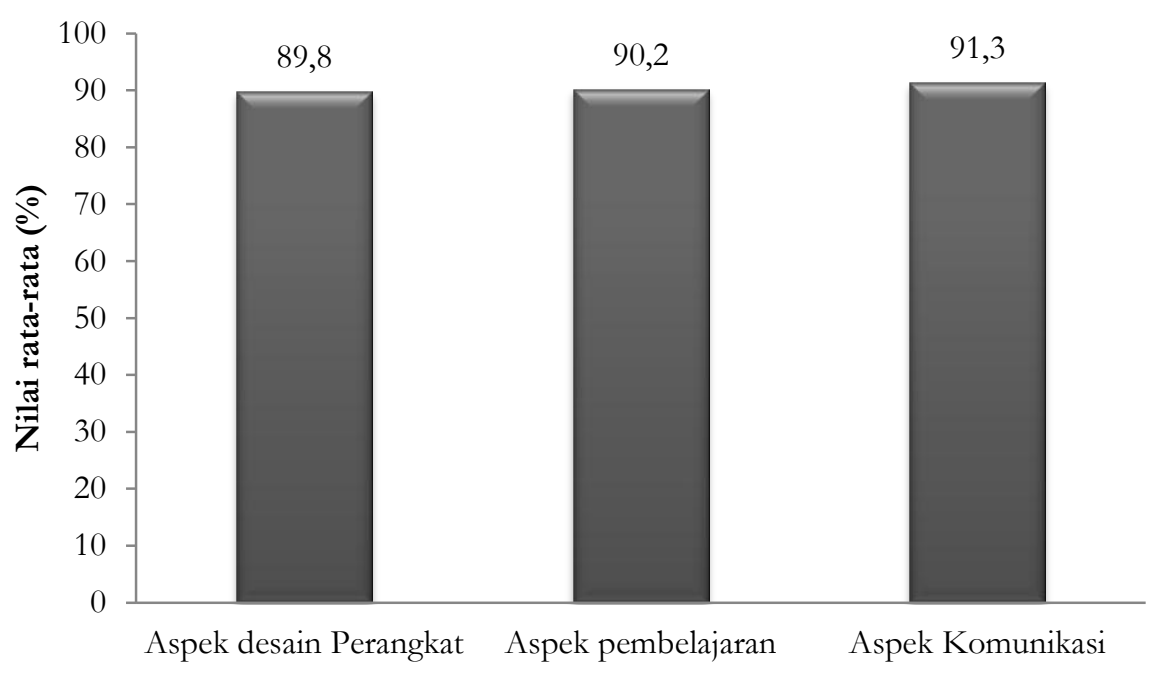

Gambar 15. Persentase Rata-rata Tanggapan Siswa 
Pada gambar 15 terlihat bahwa hasil rata-rata tanggapan siswa pada aspek desain perangkat diperoleh persentase sebesar 89,8\% dengan kategori sangat baik. Karena urutan tampilan pada menu jelas, sehingga mempermudah dalam penggunaan media ViPhyLab ini. Sesuai dengan pendapat Jaya (2016) yaitu tata letak navigasi atau tombol dapat membantu untuk mengoperasikan simulasi sehingga pengguna dapat menyelesaikan simulasi praktikum dengan baik.

Kemudian, hasil persentase pada aspek pembelajaran memiliki persentase rata-rata sebesar 90,2\% dengan kategori sangat baik. Hal ini dikarenakan media ViPhyLab yang digunakan dapat membantu untuk memahami konsep hukum kirchhoff. Sesuai dengan pendapat Hermansyah (2015) menunjukan bahwa tercapainya suatu proses pembelajaran jika adanya motiasi belajar siswa selain diri sendiri juga diperoleh dari lingkungan belajar dan sumber belajar.

Hasil rata-rata tanggapan siswa pada aspek komunikasi adalah sebesar 91,3\% dengan kategori sangat baik. Berdasarkan hasil tersebut, siswa menyatakan bahwa pemilihan jenis huruf dan warna sesuai sehingga terlihat jelas dan petunjuk penggunaan dan bahasa pada media ViPhyLab jelas sehingga mudah dipahami. Hal ini sesuai dengan pendapat Swandi (2014) yaitu pemebelajaran berbasis laboratorium virtual memberikan kesempatan bagi siswa untuk beraktivitas, bereksplorasi, dan dapat melibatkan siswa aktif.

Berdasarkan pada data di atas dapat disimpulkan bahwa media pembelajaran ViPhyLab dinyatakan layak digunakan. Kelebihan ViPhyLab adalah dapat digunakan sebagai alternatif jika praktikum hukum kirchhoff tidak dapat dilaksanakan secara nyata. Selain itu, ViPhyLab memungkinkan siswa untuk belajar secara nyaman karena alat dan bahan disimulasikan di dalam komputer sehingga tidak terlalu berbahaya. Perhitungan hasil data percobaan menggunakan ViPhyLab lebih valid dan tepat sehingga akan lebih mempermudah untuk memahami konsep yang disajikan.

Adapun kekurangan dari penelitian ini adalah adanya keterbatasan peneliti dalam memahami coding pada Action Script 2.0 software Adobe Flash Professional CS 6 yang menjadi hambatan bagi peneliti untuk mendalami seluruh komponen yang terdapat di ViPhyLab, sehingga tidak dapat membuat ViPhyLab lebih dari yang diharapkan diantaranya adalah baterai yang tidak dapat diubah nilainya dan kabel penghubung yang terdapat pada baterai tidak dapat digerakkan atau dipindahkan dalam ViPhyLab.

\section{SIMPULAN}

Berdasarkan hasil penelitian dan pembahasan dapat disimpulkan bahwa media pembelajaran Virtual Physics Lab (ViPhyLab) dalam praktikum hukum kirchhoff yang dikembangkan valid dan layak digunakan dalam pembelajaran di sekolah. Nilai persentase rata-rata hasil validasi yaitu sebesar 87,45\% sehingga media ViPhyLab dikategorikan sangat layak. Selain itu, hasil tanggapan siswa setelah menggunakan media Virtual Physics Lab (ViPhyLab) adalah sangat baik dengan persentase rata-rata sebanyak 90,4\% siswa menanggapi dengan sangat baik terhadap media Virtual Physics Lab (ViPhyLab) dalam praktikum hukum kirchhoff.

\section{REFERENSI}

Arista, F. C. (2018). Virtual Physics Laboratory Application Based on the Android to Improve Learning Independence and Conceptual Understanding. International Journal of Instruction, 11(1), 1-16.

Darman, D.R., Wibowo, F.C., Putra, A., Hasra, A. (2017). Pengembangan Buku Kerja Fisika Berbasis Kontekstual Pada Konsep Suhu Dan Kalor. Gravity: Jurnal Ilmiah Penelitian dan Pembelajaran Fisika 3 (2) 
Çelik, H., Sari U., Nugroho U. (2015). Evaluating and Developing Physics Teaching Material with Algodoo in Virtual Environment: Archimedes' Principle. International Journal of Innovation in Science and Mathematics Education, 23(4), 40-50.

Gunawan, A. (2018). Improving students' creativity using cooperative learning with virtual media on static fluida concept. International Conference on Science Education (ICoSEd), 1-6.

Gunawan \& Liliasari. (2012). Model Virtual Laboratory Fisika Modern untuk Meningkatkan Disposisi Kritis Calon Guru. Cakrawala Pendidikan (No. 2. Tahun XXXI, Juni 2012).

Jaya, H. (2011). Pengembangan Laboratorium Virtual untuk Kegiatan Praktikum dan Memfasilitasi Pendidikan Karakter di SMK. Jurnal Pendidikan Vokasi, 2(1): 81-90.

Permana, N. D. (2018). Penerapan Model Pebelajaran Learning Cycle 7E Berbantuan Website Untuk Meningkatkan Keterampilan Berpikir Kritis Siswa Pada Materi Kinematika Gerak Lurus. Journal of Natural Science and Integration, 1(1), 11-41

Putri, A. S. (2013). Pengembangan Virtual Laboratory pada Materi Kinematika dengan Analisis Vektor dalam Pembelajaran Fisika di Kelas XII SMA. Pillar Of Physics Education, 1(1): 23-29.

Rahayu, N. K., Suherman, A., \& Wibowo, F. C. (2019). Pengembangan Virtual Physics Laboratory Berbasis Website Pada Pokok Bahasan Listrik Dinamis. GRAVITY Vol.1 No.1, 64-72.

Swandi, A., Nurul S., Irsan. (2014). Pengembangan Media Pembelajaran Laboratorium Virtual untuk Mengatasi Miskonsepsi Pada Materi Fisika Inti di SMAN 1 Binamu, Jeneponto. Jurnal Fisika Indonesia, Vol XVIII (52), 20-24.

Wibowo, F.C., Suhandi, A., Rusdiana, D., Darman, D.R., Ruhiat, Y., Denny, Y.R. (2016). Microscopic virtual media (MVM) in physics learning: Case study on students understanding of heat transfer. Journal of Physics: Conference Series 739 (1), 012044

Wibowo, F.C, Suhandi, A., Samsudin, A., Darman, D.R.,Suherli, Z., Hasani, A. (2017) Virtual Microscopic Simulation (VMS) to promote students' conceptual change: A case study of heat transfer. Asia-Pacific Forum on Science Learning \& Teaching 18 (2)

Wibowo, F.C., Nurhaji, S., Setiawan, A., Sugiyarto, W. A., Noor, M., Darman, D.R., Faizin, Samsudin, A., Suhandi, A., Coştu, B. (2018). The Influences Virtual Physics Laboratory (VPL) For Assessment the Millennial Character Education through System Recording Students Character (SRSC). Journal of Education and Learning (EduLearn) 12 (4), 709-716 